\section{Epidemiology of preterm deliveries in Southeast Brazil: a hospital-based study}

\section{Epidemiologia de nascimentos pretermo no Sudeste do Brasil: um estudo de base hospitalar}

Luiz Fernando Costa Nascimento 1

1 Departamento de Pediatria. Faculdade de Medicina da Universidade de Taubaté, São Paulo.

Avenida Tiradentes, 500. Taubaté, São Paulo, Brasil.

CEP: 12.030-180. E-mail lfcnascimento@uol.com.br

\section{Abstract}

Objectives: to evaluate the role of some factors in the genesis of preterm deliveries in Southeast Brazil.

Methods: a cohort hospital-based study of 589 mothers who delivered in Taubaté, a middle-size city in the state of São Paulo, Brazil, between May 1, and October 31, 1999. The statistical approach was Risk Ratio with statistical significance established at alpha: $5 \%$.

Results: 70 preterm newborns were identified representing $11,9 \%$ of the total birth rate. The variables holding statistical significance were: previous history of stillbirth delivery, smoking during pregnancy, poor weight gain, arterial hypertension, vaginal bleeding, genitourinary tract infection and five or less medical visits for prenatal care.

Conclusions: this study indicates that good quality prenatal care has a great value in preventing preterm births, for poor weight gain, arterial hypertension, vaginal bleeding, genitourinary tract infection and smoking are conditions that can be controlled in the course of pregnancy.

Key words Infant premature, Cohort studies, Risk factors.

\section{Resumo}

Objetivos: estimar o papel de alguns fatores na gênese de recém-nascidos pré-termo no Sudeste do Brasil.

Métodos: é um estudo de coorte de base hospitalar com 589 mães que deram à luz em Taubaté, São Paulo, Brasil, entre 1 de maio e 31 de outubro de 1999; a medida de efeito deste estudo foi Risco Relativo e a significância estatística foi alfa $=5 \%$.

Resultados: foram encontrados 70 recém-nascidos pré-termo, representando 11,9\% da amostra; as variáveis com significância estatística foram história prévia de natimorto, tabagismo na gravidez, ganho de peso insuficiente, hipertensão arterial, sangramento vaginal, infecção do trato geniturinário e cinco ou menos consultas no pré-natal.

Conclusões: um pré-natal bem conduzido e de boa qualidade tem grande importância na prevenção do nascimento prematuro pois variáveis como tabagismo na gravidez, ganho de peso insuficiente, hipertensão arterial, sangramento vaginal, infecção do trato geniturinário podem ser controladas.

Palavras-chave Recém-nascido prematuro, Estudos de coortes, Fatores de risco. 


\section{Introduction}

Preterm birth is one of the most serious pregnancy care related problems. It is the most common cause of neonatal death and morbidity in surviving infants, for preterm newborns have more chances for developing long-term neurocognitive, chronic respiratory problems, intraventricular hemorrhage, infections, necrotizing enterocolitis and ophthalmologic problems. ${ }^{1-3}$

In addition, neonatal and long-term healthcare costs for preterm infants represent a considerable economic burden both on individual families and on the Country. 4

Investigations focusing on the causes of preterm birth have not succeeded in clarifying them. Because molecular and biochemical reasons for preterm births remain unknown, many investigators study the epidemiology of preterm births associated to demographic, social and medical factors. ${ }^{4-7}$ These factors are parity, maternal age, previous stillbirth and/or abortion history, arterial hypertension, vaginal bleeding, bacteriuria, educational and socioeconomic levels.

The rate of preterm birth, defined as the delivery taking place before the completion of the $37^{\text {th }}$ week of gestation, can vary between four and $17 \%$ of all births depending on the region. ${ }^{8-10} \mathrm{Al}-$ though technologic improvements in prenatal management, care and diagnosis have reduced preterm newborn mortality, the incidence of preterm births have remained relatively unchanged or even increased slightly in recent years, 4 thus, the decline in perinatal mortality is more attributable to improved neonatal care than to the reduced numbers of preterm babies.11 Preterm birth was associated to mortality during the first year of life in $31,4 \%$ of the cases reported in a study performed in the State of São Paulo in 1987.12

In Brazil, there is scarce information related to the incidence of preterm births due to the difficulty in obtaining complete and accurate information on gestation length. Mariotoni e Barros Filho 13 using a sample of 18.262 records of birth certificates of the Brazilian Ministry of Health, pertaining to the years of 1971 and 1995 , have demonstrated an incidence of 7,6 and $11,5 \%$ preterm births respectively. These results are consistent with another study performed in Ribeirão Preto, a regional University Center in Southeast Brazil14 depicting an incidence of $13,6 \%$. Both studies took place in cities in the State of São Paulo, the more developed State of Brazil.
The scope of this paper is to show the factors influencing preterm births in a cohort of pregnant women in the University Hospital of Taubaté, São Paulo, Brazil.

\section{Methods}

This is a cohort hospital-based study with primary records obtained from 589 mothers who delivered between May 1, 1999 and October 31, 1999 in the University Hospital of Taubaté. Women who had miscarriaged before the beginning of the $25^{\text {th }}$ week of pregnancy or who had not had singleton deliveries were excluded.

Taubaté is a middle-sized city, with 225.216 inhabitants 15 located between São Paulo and Rio de Janeiro, the two largest cities of Brazil.

The mothers filled a structured questionnaire, after their approval, with sociodemographic and medical information. Questions related to current and previous pregnancies. The study was approved by the Ethical Committee of the University Hospital.

The dependent variable was gestational age, in days, determined in accordance to somatic and neurologic signals and established by medical specialists (neonatologists); preterm newborns were the ones with delivery occurring before 37 weeks of gestation.

The independent variables were classified into sociodemographic and medical variables; the sociodemographic variables were maternal age, in years, classified in $\leq 19$ years old, 20 to 34 years old and $\geq 35$ years old; parity, classified as 0 previous birth and one or more births; birth interval between the last birth and the actual pregnancy, considered in months. Previous reports of spontaneous abortions or stillbirths were the other variables considered as present or absent. Smoking habits during pregnancy were ascertained and the mothers were classified as smoking and nonsmoking. Maternal educational level was classified as $\leq 8$ years of elementary school and $\geq 9$ years of high school and college. Marital status included married and cohabiting women and unmarried including widows and divorcees.

The medical variables were weight gain, obtained by the difference between habitual weight before pregnancy and the actual weight, being classified as up to $12 \mathrm{~kg}$ of gain and $13 \mathrm{~kg}$ or more; the presence of arterial hypertension defined as present or absent as informed by the mothers'medical records; vaginal bleeding considered as 
present or absent and disregarded when occurring in the first trimester of pregnancy or later, genitourinary tract infection, obtained by mother's medical records, being considered as present or absent. Time in pregnancy when the infection occurred was not considered. The number of prenatal medical visits considered were five or less and six or more.

Statistical analysis was performed using the method of relative risk (RR) 16 to compare the proportion of preterm newborns in different situations. The prevalence was calculated by the use of reference category and provided with a mark. The values of RR include 95\% Confidence Interval (95\% CI). The significance level was $\mathrm{p}<0,05$.

The sample was estimated on the basis to error $\alpha=5 \%$, error $\beta=20 \%$ and a relative risk worth detecting of 1,60; this approach yielded a sample of 530 mothers.

\section{Results}

There were 70 preterm newborns in the cohort, representing $11,9 \%$ of total deliveries.

Table 1 determines that sociodemographic factors did not indicate values with statistical significance, except for previous stillbirth deliveries and smoking in the ongoing pregnancy; previous history of stillbirth deliveries increased preterm birth risk almost three folds. Maternal age and educational level, which can be considered as distal determinants, did not indicate preterm birth risk in this sample; the study determined that age groups were not at a high risk of preterm birth.

The medical variables and preterm, term births, Relative Risk (RR), 95\% Confidence Interval $(95 \% \mathrm{CI})$, $\mathrm{p}$ values and the total of mothers are shown in the Table 2. All factors had statistical significance.

Table 1

Sociodemographic factors and preterm, term births, relative risk (RR), $95 \%$ confidence interval $(95 \% \mathrm{Cl})$, $\mathrm{p} \mathrm{values}$ and the total of mothers.

\begin{tabular}{|c|c|c|c|c|c|c|}
\hline & Preterm Birth (\%) & Term Birth (\%) & $\mathbf{R} \mathbf{R}$ & $95 \% \mathrm{Cl}$ & $\mathbf{P}$ & Total \\
\hline Maternal Age ( in years) & & & & & & 589 \\
\hline 19 or less & $20(13,2)$ & $132(86,8)$ & 1,16 & $0,70-1,93$ & NS & \\
\hline $20-34 \#$ & $36(11,4)$ & $280(88,6)$ & & & & \\
\hline 35 or more & $14(11,6)$ & $107(88,4)$ & 1,02 & $0,57-1,82$ & NS & \\
\hline Parity & & & & & & 589 \\
\hline 0 \# & $23(11,4)$ & $179(88,6)$ & & & & \\
\hline 1 or more previous birth & $47(12,1)$ & $340(87,9)$ & 1,07 & $0,67-1,72$ & NS & \\
\hline Birth interval ( in months) & & & & & & $368 *$ \\
\hline 18 mo or less \# & $10(16,1)$ & $52(83,9)$ & & & & \\
\hline 19 mo or more & $34(11,1)$ & $272(88,9)$ & 0,69 & $0,37-1,31$ & NS & \\
\hline Previous spontaneous abortion & & & & & & 589 \\
\hline Yes & $9(11,1)$ & $72(88,9)$ & & & & \\
\hline No \# & $61(12,0)$ & $446(88,0)$ & 1,08 & $0,56-2,09$ & NS & \\
\hline Previous stillbirth & & & & & & $587 * *$ \\
\hline Yes & $6(31,6)$ & $13(68,4)$ & 2,85 & $1,42-5,76$ & 0,02 & \\
\hline No \# & $63(11,1)$ & $505(88,9)$ & & & & \\
\hline Smoking & & & & & 0,02 & $551 * *$ \\
\hline Yes & $15(13,9)$ & $55(86,1)$ & & & & \\
\hline No \# & $55(11,4)$ & $426(88,6)$ & 1,87 & $1,08-3,13$ & & \\
\hline Educational level & & & & & & 589 \\
\hline Elementary & $52(12,0)$ & $282(88,0)$ & 1,03 & $0,62-1,70$ & NS & \\
\hline High Scholl and College \# & $18(11,6)$ & $137(88,4)$ & & & & \\
\hline Marital status & & & & & & $579 * *$ \\
\hline Married \# & $33(11,4)$ & $256(88,6)$ & & & NS & \\
\hline Unmarried & $37(12,8)$ & $253(87,2)$ & 1,12 & $0,72-1,74$ & & \\
\hline
\end{tabular}

\# reference, * except primiparous, ** exclude those without information, NS = no significant 
Medical variables and preterm, term births, relative risk (RR), $95 \%$ confidence interval $(95 \% \mathrm{Cl}), \mathrm{p}$ values and the total of mothers

\begin{tabular}{|c|c|c|c|c|c|c|}
\hline & Preterm Birth (\%) & Term Birth (\%) & $\mathbf{R R}$ & $95 \% \mathrm{Cl}$ & $\mathbf{P}$ & Total \\
\hline Gain of weight (in $\mathrm{kg}$ ) & & & & & & $545 * *$ \\
\hline $12 \mathrm{~kg}$ or less & $45(14,6)$ & $263(85,40)$ & 1,64 & $1,01-2,69$ & 0,04 & \\
\hline $13 \mathrm{~kg}$ or more \# & $21(8,9)$ & $216(91,1)$ & & & & \\
\hline Arterial Hypertension & & & & & & $582 * *$ \\
\hline Yes & $17(19,5)$ & $70(80,5)$ & 1,83 & $1,11-2,99$ & 0,02 & \\
\hline No\# & $53(10,7)$ & $442(89,3)$ & & & & \\
\hline Vaginal bleeding & & & & & & $587 * *$ \\
\hline Yes & $16(19,5)$ & $66(80,5)$ & 1,83 & $1,09-3,02$ & 0,02 & \\
\hline No\# & $54(10,7)$ & $451(89,3)$ & & & & \\
\hline Genitourinary tract infection & & & & & & $585 * *$ \\
\hline Yes & $29(17,2)$ & $140(82,8)$ & 1,74 & $1,12-2,70$ & 0,01 & \\
\hline No\# & $41(9,9)$ & $375(90,1)$ & & & & \\
\hline Advice in prenatal & & & & & & 589 \\
\hline 5 or less & $26(16,8)$ & $129(83,2)$ & 1,66 & $1,05-2,58$ & 0,03 & \\
\hline 6 or more & $44(10,1)$ & $390(89,9)$ & & & & \\
\hline
\end{tabular}

\# reference, ** exclude those without information, NS: not significant

\section{Discussion}

This study demonstrated related sociodemographic and medical factors to preterm births.

It consisted of a hospital-based study, identifying $11,9 \%$ of preterm births. This incidence is larger when compared with other studies in Wales and Finland.6,11 One study performed in Brazil13 shows an incidence which increased from $7,6 \%$ in the period $1971-1975$ to $11,5 \%$ in $1991-1994$, but the records were obtained through birth certificates which were not filled by medical staff and could contain a bias; the attributable cause in this study was the increase in the incidence of cesarean sections. Nevertheless, our results are consistent with a Brazilian study showing an incidence of $13,6 \% .14$

The use of gestational age determined in conformity with somatic and neurologic signals and established by medical professionals may increase the confidence of the records.

Among the sociodemographics factors only the variable of a previous history of stillbirth delivery had significance. This result coincides with other authors'findings 14,17 and does not convey a plausible explanation. Previous reports of spontaneous abortion had no significance and it has been suggested that cervical dilation associated to induced abortion may lead to cervical incompetence and consequently to preterm birth but Hogue et al. 18 have found no overall association between prior induced abortion and preterm birth. Other factors such as educational level, which can be considered a socioeconomic factor, did not show statistical significance, which is consistent with other studies.6,11,19,20 Parity, another sociodemographic factor, which was equal to zero for previous birth or one and more previous births, has shown a discrete high risk, although without statistical significance. This variable is controversial because the results are directly opposed to those of previous studies.4,6,14,17 As for maternal age, younger and older mothers had no values with statistical significance which turns this factor into a controversial one as well. 4 In respect to younger mothers, biological immaturity and the characteristics associated to adolescent pregnancy could be more important to preterm births than young 
chronological age in itself. As for older mothers, the increased incidence of preterm births could be related to primiparas and differences in maternal characteristics of the respective study population. 4

Smoking during pregnancy had related significance to preterm births as in other studies $11,19,21$ and the explanation is not easy as in the case of associated low birthweight. The other factors such as birth interval of less than 18 months and marital status had no significance, a result not consistent with other studies. 21,22

In relation to medical variables, the whole set had significance. The weight gain higher than $12 \mathrm{~kg}$ was very important to prevent preterm births. This reflected the good nutritional status of the mothers and pregnancies evolving to a good outcome.

The presence of arterial hypertension has been demonstrated to be a risk factor for preterm births. Vaginal bleeding in pregnancy, not related to pregnancy time in this paper, was an important risk factor. The RR of both factors, arterial hypertension and vaginal bleeding, was almost two folds higher for preterm births which is consistent with other studies. $4,6,7,14$

Genitourinary tract infection with bacteriuria

\section{References}

1. Rush RW, Davey DA, Segall ML. The effect of pretem delivery on perinatal mortality. Br J Obstet Gynaecol 1978; 85: 806-11.

2. McCormick MC. The contribution of low birth weight to infant mortality and childhood morbidity. N Engl J Med 1985; 312: 82-9.

3. Erkkola RU, Kero PO. Impact of prematurity on perinatal mortality and morbidity. Ann Med 1991; 23: 663-9.

4. Berkowitz GS, Papiernik E. Epidemiology of preterm birth. Epidemiol Rev 1993; 15: 414-43.

5. Savitz DA, Blackmore CA, Thorp JM. Epidemiologic characteristics of preterms delivery: etiologic heterogeneity. Am J Obstet Gynecol 1991; 164: 467-71.

6. Meis PJ, Michielutte R, Peters TJ, Wells HB, Sands RE, Coles EC, Johns KA. Factors associated with preterm birth in Cardiff, Wales. II. Indicated and spontaneous preterm birth. Am J Obstet Gynecol 1995; 173: 597-602.

7. Sanjose S, Roman E, Beral V. Low birthweight and preterm delivery, Scotland, 1981-84: effect of parents'occupation. Lancet 1991; 338: 428-31.

8. Main DM, Gabbe SG, Richardson D, Strong S. Can preterm deliveries be prevented? Am J Obstet Gynecol 1985; 151: 892-8.

9. Papiernik E, Maine D, Rush D, Richard A. Prenatal care and requiring medical treatment had significance as well, being a risk factor for preterm birth.

Finally, prenatal care, indicated by the number of medical visits during pregnancy had a protective role in the prevention of preterm births. Medical advice can prevent and treat health conditions such as arterial hypertension, genitourinary tract infection, vaginal bleeding, and poor weight gain which are risk factors. The increase of prenatal visits remains controversial, this study however indicated that a reduced number of prenatal medical visits increased the ratio of preterm births.

Variables as poor weight gain and less medical advice in prenatal care must be carefully considered for they could be the effects and not the causes of a short duration pregnancy.

Therefore, this study reveals that some risk factors such as previous stillbirth deliveries, arterial hypertension, vaginal bleeding, genitourinary tract infection and poor weight gain, occur as in other places in the world. It also shows the value of prenatal care in preventing risk factors to preterm births. Prenatal is quite easy to be attained in both public and University healthcare services in Brazil. the prevention of preterm. Int J Gynaecol Obstet 1985; 23: 427-33

10. Yan JS, Yin CS. No decline in preterm birth rate over three decades. Int J Gynaecol Obstet 1991; 34: 1-5.

11. Olsen P, Läärä E, Rantakallio P, Järvien MR, Sarpola A, Hartikainen AL. Epidemiology of preterm delivery in two birth cohorts with an interval of 20 years. Am J Epidemiol 1995; 142 : 1184-93.

12. Macharelli CA, Oliveira LR. Perfil do risco de óbito de crianças menores de um ano residentes em localidade do Estado de São Paulo, Brasil, 1987. Rev Saúde Pública 1991; 25 : 121-8.

13. Mariotoni GGB, Barros Filho, AA. Peso ao nascer e características materna ao longo de 25 anos na maternidade de Campinas. J Pediatr (Rio de Janeiro) 2000; 76: 55-64.

14. Bettiol H, Rona RJ, Chinn S, Goldani M, Barbieri MA. Factors associated with preterm births in Southeast Brazil: a comparison of two birth cohorts born 15 years apart. Pædiatr Perinatal Epidemiol 2000; 14: 30-8.

15. São Paulo (Estado). Secretaria de Saúde. População, 1998. Disponível em: < http://www.saude.sp.gov.br/html/ fr_dados.htm> [2001 set. 9].

16. Armitage P, Berry G. Statistical inference. In: Armitage P, Berry G. Statistical methods in medical research. Ox- 
ford: Blackwell Science; 1994. p. 125-32.

17. Martius JA, Steck T, Oehler MK, Wulf KH. Risk factors associated with preterm $(<37+0$ weeks $)$ and early preterm birth ( $<32+0$ weeks): univariate and multivariate analysis of 106345 singleton births from the 1994 statewide perinatal survey of Bavaria. Eur J Obstet Gynecol 1998; 80: 183-9.

18. Hogue CJR, Cates W Jr, Tietze C. The effects of induced abortion on subsequent reproduction. Epidemiol Rev 1982; 4: 66-94.

19. Fox SH, Koepsell TD, Daling JR. Birth weight and smoking during pregnancy-effect modification by maternal age. Am J Epidemiol 1994; 139: 1008-15.

20. Haidar FH, Oliveira UF, Nascimento LFC. Escolaridade materna: correlação com os indicadores obstétricos. Cad Saúde Pública 2001;17: 1025-9.
21. Wen SW, Goldenberg RL, Cutter GR, Hoffman HJ, Cliver SP, Davis RO, Du Bard MB. Smoking, maternal age, fetal growth and gestational age at delivery. Am J Obstet Gynecol 1990; 162: 53-8.

22. Shults RA, Arndt V, Olshan AF, Martin CF, Royce RA. Effects of cohort interpregnancy intervals on small-for-gestational age and preterm births. Epidemiology 1999; 10 $250-4$ 